\title{
Impact of a road on the movements of two ground beetle species (Coleoptera: Carabidae)
}

\author{
Jinze Noordijk, Debbie Prins, Marianne de Jonge \& Rikjan Vermeulen
}

Noordijk, J., Prins, D., de Jonge, M. \& Vermeulen, R. 2006: Impact of a road on the movements of two ground beetle species (Coleoptera: Carabidae). - Entomol. Fennica 17: 276-283.

We studied the effects of a road on the walking directions of the carabid species Poecilus versicolor and Agonum sexpunctatum. Using mark and recapture experiments and window traps we determined the number of road crossings and the deviation in walking directions caused by the road. We found two effects of the road on the walking behaviour: (1) the road is a barrier to both species, but whereas $P$. versicolor was reluctant to cross the road and had a significant movement away from the road, we recorded no road crossings by A. sexpunctatum; and (2) A. sexpunctatum showed a marked tendency to walk along the roadside verge, particularly in the ditch. Of these two species, only one individual of $A$. sexpunctatum was caught flying close to the road, indicating that it might cross the road by flying. Counts of dead carabid specimens on two $100 \mathrm{~m}$ long transects along the road carried out for nine weeks recorded several individuals of $P$. versicolor. We conclude with suggestions on how to implement the results of this study in nature conservation practices.

J. Noordijk, D. Prins \& M. de Jonge, Wageningen University, Department of Environmental Sciences, Nature Conservation and Plant Ecology Group, Bornsesteeg 69, 6708 PD Wageningen, the Netherlands; correspondent author's e-mail:Jinze.Noordijk@wur.nl

D. Prins, M. de Jonge \& R. Vermeulen, Stichting Willem Beijerinck Biologisch Station, Kanaaldijk 36, 9409 TV Loon, the Netherlands

Received 2 November 2005, accepted 25 March 2006

\section{Introduction}

Roads have several negative ecological effects, such as habitat destruction and disturbance and pollution of the environment (Forman \& Alexander 1998). Besides, roads also have a barrier effect: for many animals they are difficult or even impossible to cross, and many individuals end up as road kills. Various species, from snails to caribous, have been reported as having difficulty in crossing roads (Baur \& Baur 1990, Mader et al.
1990, Dyer et al. 2002, Koivula \& Vermeulen 2005). Those species isolated in areas cut off by roads may suffer a loss of genetic variability within the populations (Reh \& Seitz 1990, Keller \& Largiadèr 2003), which might increase the probability of local extinctions (Pulliam \& Dunning 1997).

In 2005 we studied carabid movement patterns next to a provincial road running straight through the centre of the Mantingerveld nature restoration area, in the north of the Netherlands 
Fig. 1. Location and development of the Mantingerveld nature restoration area, illustrated by maps of the area. The provincial road studied runs through the middle of this area. White areas are arable fields, grey areas are heathlands (and in 1d are also former arable fields), and black areas are forests. - a. Location of the Mantingerveld in the north of the Netherlands (black square). - b. Situation in 1954. -c. Situation in 1990. - d. Situation in 2004. The location of the road enclosure is indicated by a circle with a cross.
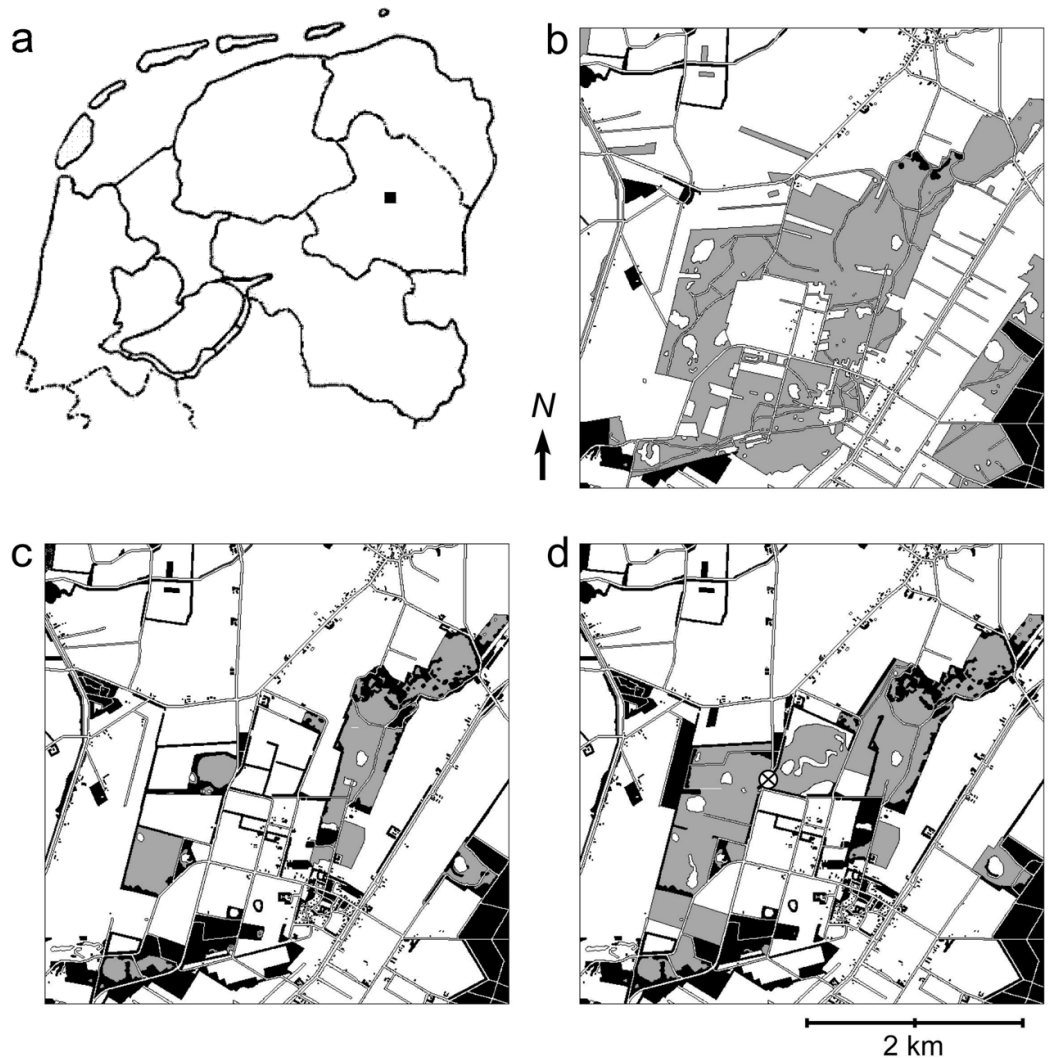

(Fig. 1a). In this area, the conversion of more than 2,000 ha of heathland into arable land started in 1954 (Fig. 1b). By 1959, only 325 ha of heathland remained, scattered throughout the area in five fragments. This situation persisted until the late 1990s (Fig. 1c). In the Netherlands, habitat fragmentation and destruction began to attract public concern in the 1970s and 1980s, resulting in the planning of the restoration, enlargement, and reconnection of the remaining heathlands. In order to connect the five remnants of heathland in the Mantingerveld, the Dutch nature management organisation 'Natuurmonumenten' is restoring the intervening arable fields into heathland and species-rich grassland by removing topsoil and introducing heather propagules (Aerts et al. 1995). This strategy has led to a more or less coherent and interconnected nature reserve with a total area of 1050 ha (Fig. 1d). However, the road still divides the Mantingerveld in two.

Previous research on the barrier effect of roads on carabid species has focussed on forest species (Mader 1984, Keller \& Largiadèr 2003,
Koivula \& Vermeulen 2005). Mader et al. (1990) found that even narrow field tracks already had some barrier effect on a mix of open area carabid species, but they did not discuss species-specific results. In this paper we examine whether a road between two areas with relatively xeric and thermic habitats is a barrier to two carabid species that are abundant in the area. We measure whether successful crossings do occur by walking or flying, and whether carabid beetles are killed by traffic. We discuss whether the road affects the direction of movement of the two carabi$\mathrm{d}$ species, as if this is the case, this may hinder the free exchange of individuals or even species between the areas on either side of the road.

\section{Material and methods}

\subsection{Location and study species}

The N317 (known locally as the Hoogeveenseweg) is a provincial road with an asphalted sur- 
face $6.5 \mathrm{~m}$ wide, constructed around 1968 and connecting the village of Westerbork with the town of Hoogeveen. The field site $\left(52^{\circ} 46^{\prime} \mathrm{N}\right.$, $6^{\circ} 35^{\prime}$ E) straddles a stretch of the road in the nature restoration area that is bordered to the west by the Hullenzand heath and to the east by a former arable field, the Groote Veld (Fig. 1d). On average, 2,400 cars use this road per day (data supplied by Drenthe Province). On either side of the road is a grassy verge. On the heathland side, about $2 \mathrm{~m}$ from the road, the verge is separated from the heathland by a dry ditch.

We used Poecilus versicolor (Sturm, 1824) and Agonum sexpunctatum (Linnaeus, 1758) to study carabid walking behaviour close to the road. These species were selected because they are common in the heathland area and the oligotrophic former arable fields seem to provide a suitable habitat for them (Verhagen \& Vermeulen 2005).

Poecilus versicolor is a eurytopic species of open areas (Turin et al. 1991). Though it can be found in various types of low vegetation on various types of soil, in the Netherlands it prefers sandy soils, and is most abundant in heathland (Turin 2000). It is macropterous and capable of flying, but only a small percentage of the population has the opportunity to develop wing muscles (Desender 1989). P. versicolor has been recorded in the Groote Veld, but in very low densities compared with the Hullenzand heathland (Verhagen \& Vermeulen 2005).

In the Netherlands, the second species, Agonum sexpunctatum, is a characteristic species of oligotrophic humid heathland areas (Turin et al. 1991), although it can occur in other types of habitat. The species is macropterous and capable of flying, but a proportion of the population has reduced wings (Desender 1989). A. sexpunctatum is common in the Hullenzand heath and was recently discovered in the Groote Veld (Arnold Spee, pers. comm.).

\subsection{Experimental enclosures}

Using hardboard fencing we made two circular enclosures to test whether the presence of a road altered the direction of movement of the two carabid species (Fig. 2). One enclosure straddled

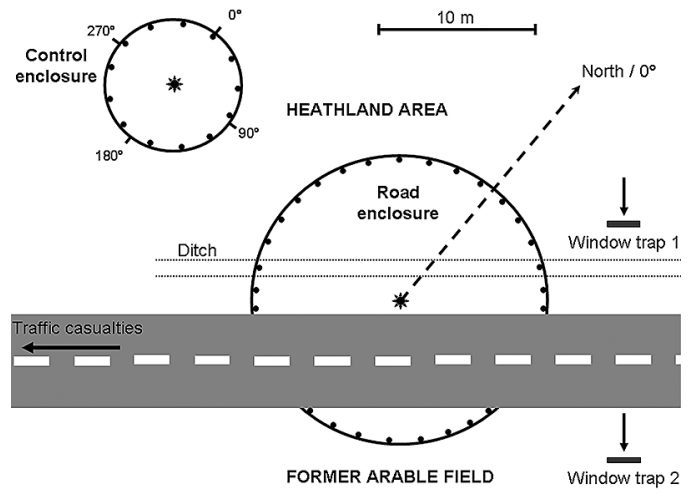

Fig. 2. Schematic representation of the experimental set-up in the field. Indicated are the locations of the road and control enclosure, including all the pitfall traps (black circles). Marked beetles were released at the centre of each enclosure (black stars). The transects for collecting traffic casualties were located in the direction of the arrow. The window traps only intercepted carabids flying from the heathland towards the former arable field.

the road and the other, a control, was in the heath about $30 \mathrm{~m}$ away from the road enclosure. The diameter of the road enclosure was $19.4 \mathrm{~m}$ and that of the control enclosure $8.4 \mathrm{~m}$. Carabids were collected in the surrounding area and marked by making small pits in the elytra with a tiny soldering iron. The marked individuals were released in the centre of the two enclosures. Dry pitfall traps (diameter $10 \mathrm{~cm}$, depth $9 \mathrm{~cm}$ ) were placed about two $\mathrm{m}$ apart on the inside of the fence, all at the same distance from the release point. There were 13 traps in the control enclosure and 27 in the road enclosure. In the road enclosure, 1,188 individuals of $P$. versicolor and 113 individuals of $A$. sexpunctatum were released. The corresponding numbers for the control enclosure were 342 and 39 individuals. We recorded all individuals trapped in the individual pitfall traps.

The pitfall traps in the circular enclosures were clockwise given values between $0^{\circ}$ and $360^{\circ}$, starting with $0^{\circ}$ at north and proceeding clockwise. In the road enclosure the pitfall traps between $295^{\circ}$ and $345^{\circ}$ were excluded from statistical analysis, to compensate for the gaps in the enclosure caused by the road. In this way an even distribution of sampling points was created, allowing the directional preferences of the carabid beetles to be calculated. The directional prefer- 
Fig. 3. Recapture results of the road and the control enclosure for both carabid species. The triangles indicate the direction of the pitfalls (attached to the fence) where the individuals were caught. The length of the triangles is proportional to the number of recaptures in that direction and is not comparable between the circles. $-a$. Walking pattern of $P$. versicolor in the road circle (380 individuals). $-\mathrm{b}$. Walking pattern of $A$. sexpunctatum in the road circle (45 individuals). - c. Walking pattern of $P$. versicolor in the control circle (164 individuals). d. Walking pattern of $A$. sexpunctatum in the control circle (13 individuals).
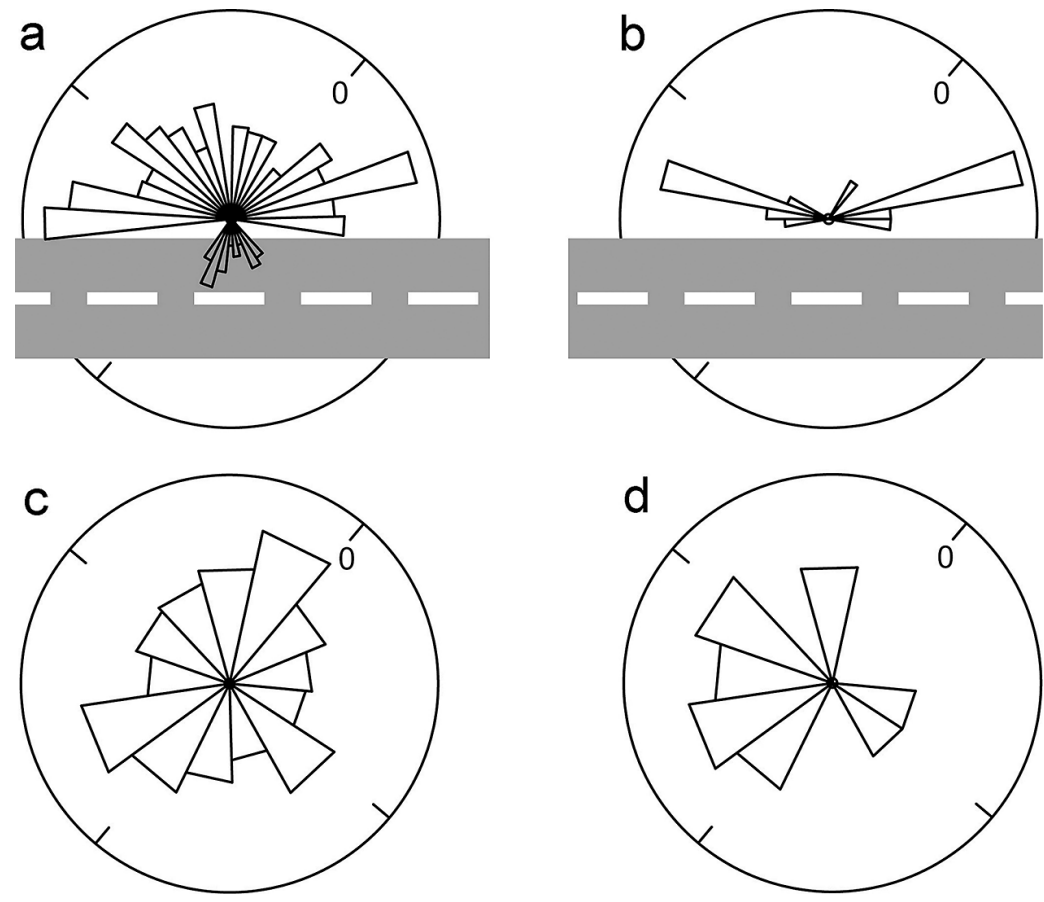

ences in both enclosures, expressed as mean vector length and mean angle, were calculated according to Batschelet (1981), using the number of recaptures in the different traps. To study a possible bimodal directional preference, the data were transformed by multiplying the angle of each recaptured individual by two and then recalculating the mean vector and angle.

The significance of mean angles was analysed with a Rayleigh test for randomness (Batschelet 1981). Differences in distribution of walking preferences between the road and the control enclosure were analysed with chi-square tests, after pooling the pitfall traps in both enclosures in three parts (between $225-295^{\circ}, 345-55^{\circ}$ and $105-$ $\left.175^{\circ}\right)$.

\subsection{Traffic casualties}

During nine weeks (from 31 March to 3 June) we collected and identified carabids killed by traffic. The collection was done daily on weekdays, on two transects of $100 \mathrm{~m}$ over the entire asphalted surface of the road and extending one metre into the verge on either side. It took approximately 30 minutes to finish one transect. One transect was close to the road enclosure, between the heathland and the former arable field. The second transect was between some patches of woodland and an arable field.

\subsection{Window traps}

On either side of the road we placed a window trap close to the road to intercept carabids flying from the heathland towards the former arable field (Fig. 2). A plexiglass window $(1 \mathrm{~m} \times 1 \mathrm{~m})$ in a metal frame was positioned with its lower edge about one metre above ground level. A $15 \mathrm{~cm}$ wide gutter filled with a formalin solution was placed under one side of the window to collect carabids that flew into the window en route to the former arable field. The window traps were emptied weekly from 15 April to 26 May.

\section{Results}

\subsection{Experimental enclosures}

In the road enclosure the recapture rate for $P$. versicolor was 32\% (380 individuals). Twenty- 
Table 1. Carabids found dead on the road and in a small strip of both verges. The collection was done on two transects of $100 \mathrm{~m}$; transect 1 was located in between the heathland and the former arable field, transect 2 was between some patches of woodland and an arable field.

$\begin{array}{lrr}\text { Species } & \text { Tran- } & \text { Tran- } \\ \text { sect } 1 & \text { sect } 2\end{array}$

Amara nitida Sturm, 1825

Amara sp. sect 1 sect 2

Calathus melanocephalus (Linnaeus, 1758)

Carabus arvensis Herbst, 1784

Carabus nemoralis Müller, 1764

Carabus problematicus Herbst, 1786

Harpalus affinis (Schrank, 1781)

Harpalus sp.

Poecilus versicolor (Sturm, 1824)

Pterostichus niger (Schaller, 1783)

Pterostichus oblongopunctatus

(Fabricius, 1787)
Table 2. Carabid species caught using window traps placed on either side of the road to capture beetles flying from the heathland towards the former arable field. Window trap 1 was located at the heathland side of the road and window trap 2 was located on the former arable field side of the road.

Species

Trap 1 Trap 2

Acupalpus brunnipes (Sturm, 1825)

Agonum meulleri (Herbst, 1784) 7

11

Agonum sexpunctatum (Linnaeus, 1758)

Amara aenea (Degeer, 1774)

Amara anthobia Villa \& Villa, 1833

Amara famelica Zimmermann, 1832

Amara lunicollis Schiødte, 1837

Amara nitida Sturm, 1825

Amara plebeja (Gyllenhal, 1810)

Amara similata (Gyllenhal, 1810)

Anchomenus dorsale (Pontoppidan, 1763)

Ansiodactylus binotatus (Fabricius, 1787)

Calathus melanocephalus (Linnaeus, 1758)

Harpalus rufipalpis Sturm, 1818

four of the 380 recaptured individuals had crossed the road. This is far fewer than would be expected if the beetle movements were random. $P$. versicolor showed a significant movement perpendicular to the road, with the mean angle being $298^{\circ}(r=23.0, \mathrm{df}=331, p<0.001)$ (Fig. 3a).

In the road enclosure the recapture rate for A. sexpunctatum was $39 \%$ (45 individuals). The barrier effect of the road for A. sexpunctatum was even stronger: not a single individual had crossed the road. However, no single preferred direction was found for this species, apparently because the data exhibited a very strong bimodal directional preference alongside the road, particularly in the ditch (Fig. 3b). A modified Rayleigh test confirmed this $(r=0.88, \mathrm{df}=44, p<0.001)$.

In the control enclosure the recapture rates for $P$. versicolor and $A$. sexpunctatum were respectively 48\% (164 individuals) and 33\% (13 individuals). No directional preference was found for $P$. versicolor in this enclosure (Fig. 3c). Though A. sexpunctatum had a preference for the southwest, with the mean angle being $217^{\circ}(r=0.50$, df $=14, p=0.027$ ) (Fig. 3d). We attribute this finding to the low number of recaptures.

Comparing the distribution of the walking directions of $P$. versicolor and $A$. sexpunctatum in
Pterostichus vernalis (Panzer, 1796) 14

Stenolophus teutonus (Schranck, 1781)

the road enclosure with those in the control enclosure revealed a clear difference in direction of movement for both species $\left(\chi^{2}=50.7, \mathrm{df}=2, p\right.$ $<0.001$ for the former and $\chi^{2}=14.1$, df $=2, p$ $<0.001$ for the latter species).

\subsection{Traffic casualties}

We collected 29 dead individuals of eight carabid species from the road (Table 1). These included seven individuals of $P$. versicolor and three individuals of the stenotopic heathland species Carabus arvensis Herbst, 1784.

\subsection{Window traps}

We collected 272 individuals of eighteen carabid species from the window traps that intercepted flights from the heathland towards the former arable field (Table 2). The catches included one indi-
Pterostichus strenuus (Panzer, 1797) 
vidual of $A$. sexpunctatum, but it was in the window trap on the heathland side of the road. No other heathland or driftsand species were trapped in the window traps.

\section{Discussion}

\subsection{Effects of the road}

We found two effects of the road on the walking behaviour of the two carabid species. Firstly, the road prevents both species from moving freely between the areas on both sides of the road: We base this assertion on our finding that $P$. versicolor rarely crossed the road and had a significant preference to move away from the road, and on the lack of recorded instances of $A$. sexpunctatum crossing the road. The stronger reaction of $A$. sexpunctatum might be caused by the fact that it is smaller than $P$. versicolor and is more restricted to humid situations, so it will experience the asphalt as an unsuitable environment. Similar barrier effects have been found for other carabids (Mader 1984, Koivula \& Vermeulen 2005). Our experiment confirms that roads are barriers in heathland landscapes too. From this we infer that in the Mantingerveld area - that is fragmented by the road - there must be isolated populations of some carabid species. The fragmented heathland also reduces the likelihood of carabids colonizing the former arable fields.

The second effect of the road we found was the marked tendency of $A$. sexpunctatum to walk alongside the road, particularly in the ditch. Individuals of $P$. versicolor also seemed to have a preference for paralleling the road and walking in the ditch. Mader et al. (1990) found similar reactions of carabids to roads and a railway track. This tendency to move parallel to transport routes might lead carabids away from their habitat and it might also increase the distance they have to travel before reaching the next suitable site, with the risk that their energy supply will be exhausted before they reach that site (Mader et al. 1990). Both carabid species we studied are rather common and not particularly vulnerable, so we expect the road to be an even more prominent barrier to more stenotopic animals, especially if they are small and/or flightless.
We found three individuals of $C$. arvensis killed by traffic. This stenotopic heathland species is considered rare in the Netherlands (Turin 2000). Other road kills we found included mammals, birds, amphibians and a reptile (data not shown). These findings illustrate that traffic has a direct impact on target species of heathland conservation, especially considering the discrepancy between the number of animals killed by traffic and the low number of individuals found during surveys (Slater 2002). Our failure to trap specific heathland and driftsand carabid species flying close to the road (except for one individual of $A$. sexpunctatum) indicates the possibility that even flying stenotopic species may experience roads as barriers (Askling \& Bergman 2003, Bhattacharya et al. 2003, Laurance et al. 2004).

We conclude that although 'Natuurmonumenten' aims at developing the Mantingerveld into one coherent nature reserve, the road prevents carabids from moving freely and also puts their populations under extra pressure by causing deaths of individuals.

\subsection{Suggestions for reducing the barrier effect}

The best way to undo the barrier effect of the provincial road is to relocate the road outside the nature restoration area, but this is not a realistic option. A successful mitigation measure for the heathland species might be a wildlife overpass. Almost no literature exists on the use of wildlife overpasses by carabid beetles, so the effectiveness of these structures is largely unknown. Only Rietze (2002) has shown that several carabid species use wildlife overpasses to cross the road when the vegetation of the source area is similar to the vegetation on the overpass and habitat corridors towards the overpass are provided (see also Luell et al. 2003). However, species of moist and wet habitats are unlikely to use such structures (Rietze 2002).

A broad overpass would function better than a narrow one and it would be best for the road to go through a tunnel, so that the overpass would be at the same level as the surrounding landscape. If the overpass is covered with the preferred vegetation of the target species of the Mantingerveld, a 
heathland mosaic, stenotopic species might be able to cross the road, and large or eurytopic animals could cross the road without being killed.

\subsection{Dealing with the bimodal walking behaviour}

Our finding that carabid beetles prefer walking alongside the road and in the ditch, suggests that roads and their associated infrastructure can lead them away from their habitat. This might be ameliorated by constructing attractive roadside verges. The verges and ditches in a certain area or habitat type should also end up in the same type of area or habitat. Roadside verges should be integrated into the nature reserves and should not lead species away to unsuitable habitats. On the other hand, roadside verges can themselves provide a habitat for certain target species (e.g., Vermeulen 1993, Eversham \& Telfer 1994).

The tendency of the carabids to walk alongside the road suggests that verges could not only be exploited to lead carabids towards a wildlife overpass, but also from one area to another. This corridor function could be strengthened if the verges consist of the typical vegetation of the two areas to be connected, are not too long, and are also an attractive environment for carabid reproduction (Getz et al. 1978, Vermeulen 1993). In this way, the usually unavoidable presence of roads and the accompanying verges might be exploited to provide helpful connections between scattered nature reserves.

Acknowledgements. We are grateful to Natuurmonumenten for allowing the experiments and financial support. JN receives a research grant from the Road and Hydraulic Engineering Division of the Ministry of Transport, Public Works and Water Management. Arnold Spee was a great field assistant. André Schaffers and Karlè Sýkora were helpful in analysing the data and discussing the results. Florian Kohler improved an earlier version of the paper. Bjorn Robroek helped with the figures. Joy Burrough improved the English of the manuscript.

\section{References}

Aerts, R., Huiszoon, A., van Oostrum, J. H. A., van de Vijver, C. A. D. M. \& Willems, J. H. 1995: The potential for heathland restoration on formerly arable land at a site in Drenthe, The Netherlands. - Journal of Applied Ecology 32: 827-835.

Askling, J. \& Bergman, K.-O. 2003: Invertebrates - a forgotten group of animals in infrastructure planning? Butterflies as tools and model organisms in Sweden. - Proceedings of the International Conference on Ecology and Transportation 2003: 476-482. URL: http://www.icoet.net/downloads/03Birds\&Insects. pdf

Batschelet, E. 1981: Circular statistics in biology. - Academic Press, London. 371 pp.

Baur, A. \& Baur, B. 1990: Are roads barriers to dispersal in the land snail Arianta arbustorum? - Canadian Journal of Zoology 68: 613-617.

Bhattacharya, M., Primack, R. B. \& Gerwein, J. 2003: Are roads and railroads barriers to bumblebee movement in a temperate suburban conservation area? - Biological Conservation 109: 37-45.

Desender, K. 1989: (Dispersal ability and ecology of carabid beetles (Coleoptera, Carabidae) in Belgium: an evolutionary approach). - Studiedocumenten van het Koninklijk Belgisch Instituut voor Natuurwetenschappen 54. 136 pp. [In Dutch.]

Dyer, S. J., O’Neill, J. P., Wasel, S. M. \& Boutin, S. 2002: Quantifying barrier effects of roads and seismic lines on movements of female woodland caribou in northeastern Alberta. - Canadian Journal of Zoology 80: 839-845.

Eversham, B. C. \& Telfer, M. G. 1994: Conservation value of roadside verges for stenotopic heathland Carabidae: corridors or refugia? - Biodiversity and Conservation 3: 538-545.

Forman, R. T. T. \& Alexander, L. E. 1998: Roads and their major ecological effects. - Annual Review of Ecology and Systematics 29: 207-231.

Getz, L. L., Cole, F. R. \& Gates, D. L. 1978: Interstate roadsides as dispersal routes for Microtus pennsylvanicus. - Journal of Mammalogy 59: 208-212.

Keller, I. \& Largiadèr, C. R. 2003: Recent habitat fragmentation caused by major roads leads to reduction of gene flow and loss of genetic variability in ground beetles. - Proceedings of the Royal Society of London B 270: 417-423.

Koivula, M. J. \& Vermeulen, H. J. W. 2005: Highways and forest fragmentation - effects on carabid beetles ( $\mathrm{Co}-$ leoptera, Carabidae). — Landscape Ecology 20: 911926.

Laurance, S. G. W., Stouffer, P. C. \& Laurance, W. F. 2004: Effects of road clearings on movement patterns of understory rainforest birds in central Amazonia. Conservation Biology 18: 1099-1109.

Luell, B., Bekker, G. J., Cuperus, R., Dufek, J., Fry, G., Hicks, C., Hlaváč, V., Keller, V., Rosell, C., Sangwine, T., Tørsløv, N. \& le Maire-wandall, B. 2003: Wildlife and Traffic: A European handbook for identifying conflicts and designing solutions. - KNNV publishers, Utrecht. 176 pp.

Mader, H. J. 1984: Animal habitat isolation by roads and agricultural fields. - Biological Conservation 29: 8196. 
Mader, H. J., Schell, C. \& Kornacker, P. 1990: Linear barriers to arthropod movements in the landscape. - Biological Conservation 54: 209-222.

Pulliam, H. R. \& Dunning, J. B. 1997: Demographic processes: population dynamics on heterogeneous landscapes. - In: Meffe, G. K. \& Carroll, C. R. (eds.), Principles of conservation Biology, second edition: 203-232. Sinauer Associates Publishers, Sunderland, $729 \mathrm{pp}$.

Reh, W. \& Seitz, A. 1990: The influence of land use on the genetic structure of populations of the common frog Rana temporaria. - Biological Conservation 54: 239-249.

Rietze, J. 2002: (The effectiveness of wildlife overpasses ("green bridges") over roads using the example of ground beetles - methods, experiences and results). Angewandte Carabidologie 4-5: 63-93. [In German.]

Slater, F. M. 2002: An assessment of wildlife road casualties - the potential discrepancy between numbers counted and numbers killed. - Web Ecology 3: 3342.
Turin, H. 2000: [Fauna of the Netherlands 3. The Dutch carabid beetles: distribution and ecology. (Coleoptera: Carabidae)]. - Nationaal Natuurhistorisch Museum Naturalis. KNNV uitgeverij, European Invertebrate Survey, Leiden. 666 pp. [In Dutch.]

Turin, H., Alders, K., den Boer, P. J., van Essen, S., Heijerman, Th., Laane, W. \& Penterman, E. 1991: Ecological characterization of carabid species (Coleoptera, Carabidae) in The Netherlands from thirty years of pitfall sampling. - Tijdschrift voor Entomologie 134: 279-304.

Verhagen, R. \& Vermeulen, R. 2005: (The carabid beetles of the Mantingerveld. Illustration of the effects of habitat fragmentation and the measures for defragmentation). - Stichting Willem Beijerinck Biologisch Station, Loon, the Netherlands, 65 pp. [In Dutch.]

Vermeulen, H. J. W. 1993: The composition of the carabid fauna on poor sandy road-side verges in relation with comparable open areas. - Biodiversity and Conservation 2 : $331-350$. 